\title{
New Publications from NORDICOM
}

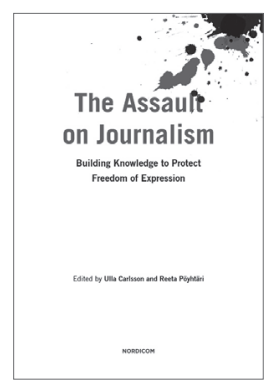

The Assault on

Journalism

Building knowledge to protect

freedcom of expression

Ulla Carlsson \& Reeta Pö-

yhteri (eds.) Nordicom 2017,

$378 \mathrm{p}$.

In connection with World Press Freedom Day 2016 in Helsinki an international conference, entitled Safety of Journalists.

Knowledge is the Key, was arranged by UNESCO and the UNESCO Chair on Freedom of Expression at the University of Gothenburg in collaboration with IAM$\mathrm{CR}$ ), and a range of other partners.

The aim of the publication is to highlight and fuel journalist safety as a field of research, as well as to inspire further dialogues and new research initiatives. The contributions represent diverse perspectives on both empirical and theoretical research and offer many quantitatively and qualitatively informed insights.

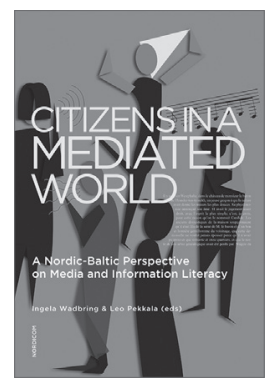

\section{Citizens in a Mediated} World

A Nordic-Baltic perspective on media and information Ingela Wadbring \& Leo Pekkala (eds.) Nordicom 2017, $108 \mathrm{p}$.

Digital technology has become a natural part of our daily lives and requires new skills, knowledge and attitudes.

This book presents the discussions and conclusions from a conference on Media and Information Literacy in Helsinki, May 2016, financed by the Nordic Council of Ministers. The event was organized by Nordicom together with KAVI - National Audiovisual Institute in Finland, jointly with the Nordic media and media education authorities: Media Council for Children and Youth in Denmark, Fjölmiðlanefnd (The Media Commission) of Iceland, Norwegian Media Authority and the Swedish Media Council.

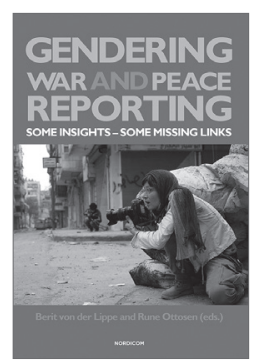

Gendering War and Peace Reporting

Some insights - some missing links

Berit von der Lippe \& Rune Ottosen (eds.) Nordicom 2016, $278 \mathrm{p}$.

War reporting has traditionally been a male activity. Elite sources like politicians, high ranking military officers and state officials are collectively still dominated by men, and it will take more than the presence of an increased number of female journalists to change this male hegemony.

There is, though, no deterministic link between sex/gender and more peaceful news or a more peaceful world.

This book offers analytic approaches to how traditional war journalism is gendered. Through different case studies, the book reveals how the framing of different femininities and masculinities affects the reporting and our understanding of war and conflicts.

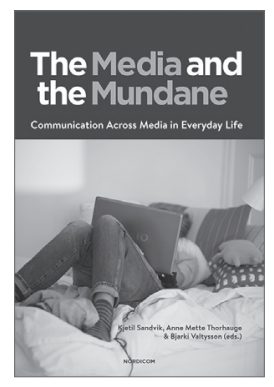

\section{The Media and the Mundane}

Communication across media in everyday life

Kjetil Sandvik, Anne Mette Thorhauge \& Bjarki Valtysson (eds.) Nordicom 2016, $159 \mathrm{p}$.

This book provides a variety of cases and theoretical insights that touch upon communication across media in everyday life. The cases favour user perspectives and are focused on coordinating mundane activities on smartphones, the role played by apps when exercising, the use of self-organised Facebook groups for civic participation, the role various cross-media communication patterns play in the everyday practices of bereaved parents, the framing and use of digitized cultural heritage, and the political everyday life appropriations of users on social media. While the cases are empirically grounded, the theoretical insights provide different frameworks for understanding cross-mediated communication patterns and space of agency in everyday contexts.

\section{Also available in full text online at www.nordicom.gu.se}

